Review

\title{
Variants of Ranked-Choice Voting from a Strategic Perspective
}

\author{
Jack Santucci \\ Department of Politics, Drexel University, Philadelphia, PA 19104, USA; E-Mail: jas948@drexel.edu
}

Submitted: 21 December 2020 | Accepted: 17 March 2021 | Published: 15 June 2021

\begin{abstract}
Ranked-choice voting has come to mean a range of electoral systems. Broadly, they can facilitate (a) majority winners in single-seat districts, (b) majority rule with minority representation in multi-seat districts, or (c) majority sweeps in multiseat districts. Further, such systems can combine with rules to encourage/discourage slate voting. This article describes five major versions used, abandoned, and/or proposed for US public elections: alternative vote, single transferable vote, block-preferential voting, the bottoms-up system, and alternative vote with numbered posts. It then considers each from the perspective of a 'political strategist.' Simple models of voting (one with two parties, another with three) draw attention to real-world strategic issues: effects on minority representation, importance of party cues, and reasons for the political strategist to care about how voters rank choices. Unsurprisingly, different rules produce different outcomes with the same sets of ballots. Specific problems from the strategist's perspective are: 'majority reversal,' serving 'two masters,' and undisciplined third-party voters (or 'pure' independents). Some of these stem from well-known phenomena, e.g., ranking truncation and 'vote leakage.' The article also alludes to 'vote-management' tactics, i.e., rationing nominations and ensuring even distributions of first-choice votes. Illustrative examples come from American history and comparative politics. A running theme is the two-pronged failure of the Progressive Era reform wave: with respect to minority representation, then ranked voting's durability.
\end{abstract}

\section{Keywords}

alternative vote; ballot exhaustion; block-preferential voting; bottoms-up system; exhaustive-preferential system; instant runoff voting; ranked-choice voting; open-list proportional representation; single transferable vote; strategic coordination

\section{Issue}

This review is part of the issue "The Politics, Promise and Peril of Ranked Choice Voting" edited by Caroline Tolbert (University of lowa, USA).

(C) 2021 by the author; licensee Cogitatio (Lisbon, Portugal). This review is licensed under a Creative Commons Attribution 4.0 International License (CC BY).

\section{Introduction}

Over the course of the past two decades, various forms of ranked-choice voting (RCV) have been adopted in the US. These include at the local and state levels, with and without partisan elections, and sometimes for party primaries. These RCV forms, as I will show below, have different implications for campaign strategy, minority representation, and coalition politics. Yet popular discourse has emphasized the ballot type (ranked), which is just one part of a larger electoral system. Other key features are district magnitude (the number of seats per district), allocation rule (how votes turn into seats), the size of an assembly (Rae, 1967; Shugart \& Taagepera, 2020), and rules that do or do not encourage coalition-minded bal- lot marking (e.g., unique party labels, compulsory ranking, a ticket-voting option). The emerging literature in American politics has focused on just one form of RCV, where district magnitude equals one. This article introduces four other types, as well as a series of strategic issues arising under them. One is minority representation in the presence of polarized voting.

For the purpose of what follows, RCV means an electoral system in which voters rank candidates and ballots transfer to next-ranked picks until all seats in a district are filled. Broadly, such systems can facilitate (a) majority winners in single-seat districts, (b) majority rule with minority representation in multi-seat districts, or (c) majority sweeps in multi-seat districts. They can also facilitate single-party, multi-party, or weak-party 
government. Facilitate is a good term because much depends on how (and whether) voters rank choices.

This review adopts the perspective of a winningminded strategist. Winning can refer to just one seat or control of the entire government (cf. Cox, 1997). Hence the essay is about strategic coordination, not strategic voting. An assumption is that parties-or multi-party coalitions, or party-like formations-will emerge under RCV (cf. Aldrich, 1995). Then their leaders will take interest in how and whether voters rank choices (Laver, 2000). Stories of campaign strategy below will substantiate the emphasis on leadership.

Reformers may dispute my focus on elites, especially because their work proceeds in a context of frustration with the parties (McCarthy \& Santucci, 2021). Yet it may be helpful to grapple with two facts, both of which relate to organized electoral competition in post-reform environments.

One fact is the near-universal repeal of RCV systems in the late Progressive Era and New Deal. Of these, just two remain: Cambridge (MA) and Arden (DE). Many of my vignettes draw from such historic cases.

Although a comprehensive account of repeal is impossible in this article, one overarching possibility stands out: trying to use reform to create a multi-party system, versus introducing reform where multiple parties already exist. In most other RCV democracies, such systems have been imposed to manage existing (or incipient) multi-party competition: Australia (Farrell \& McAllister, 2006a), Ireland (Gallagher, 2005, pp. 512-514), Malta (Hirczy de Miño \& Lane, 1996, p. 24), Northern Ireland (McGarry \& O'Leary, 2006), New Zealand (Cheyne \& Comrie, 2005), Scotland (Curtice, 2007), and most recently Wales (Slaughter, 2020). In the US, by contrast, two-party politics have been constant. Therefore, RCV adoptions in the US have been, by necessity, about managing (e.g., Santucci, 2018a; Weeks, 1937) or creating (e.g., Gehl \& Porter, 2020; Porter, 1914) intra-party factionalism. Differences between 'multiparty politics' and 'two-party factionalism' may help explain RCV's historic instability in the US. Note that, in repeal campaigns, opposing party bosses often blamed these systems for producing a "lottery effect" (Straetz, 1958, pp. 13, 31, 37; cf. Weaver, 1986, pp. 142-143). This suggests widespread frustration with unpredictable outcomes-both from elections and politics inside of legislatures (see, e.g., the 'two masters' problem noted in Section 4). These problems are less common in multiparty RCV democracies.

Second is that seemingly minor RCV details can reduce minority representation. Such effects may not be foreseeable when voting coalitions are in flux, i.e., the very conditions propelling many RCV adoptions. But modern reformers need to know that many of their predecessors' 'wins' occurred in a context of voting restriction (Bridges \& Kronick, 1999, p. 693). As US voting rights expanded to a larger share of the population, effects of the other details became visible (cf. Trebbi, Aghion, \&
Alesina, 2008, p. 345). Those details include small assemblies, numbered posts, nonpartisan ballots, and citywide plurality-majority elections (which replaced or outlasted RCV). Block-preferential RCV, also covered below, could play a similar role today.

The essay begins with RCV 'forms' that have been used for US public elections. Section 2 sketches a simple model of voting and seat allocation in each form. This shows what happens when voting is polarized and voters are able to rank all choices. The model draws attention to several issues that might concern a strategist: mechanical effects on minority representation, consequences of strong/weak party cues, problems from voters' non-use of rankings, and problems from cross-aisle preference flows (referred to here as majority reversal and serving two masters). I allude to the problem of vote management, or optimizing the number of nominees and how votes are distributed among them.

Sections 5 and 6 introduce a third party. This is because having more parties is a major goal for some reformers (e.g., Drutman, 2020, on multi-seat districts). Meanwhile, others aim to have more non-party independents (e.g., Gehl \& Porter, 2020, on single-seat districts without party nominations). The three-party model addresses both constituencies. Its core results are: outcome sensitivity to small variation in third-party vote distribution, this group's pivotal status, and (counterintuitively) that the 'proportional' system (single transferable vote, henceforth STV) minimizes its impact on majorparty seat shares. The essay concludes with a summary of core points.

\section{Types of Ranked Voting in the US}

Most RCV systems derive from STV, so that is worth describing up front. A candidate must meet a win threshold (technically a quota), usually defined as: (total valid votes)/(seats in district +1$)+1$. Votes above the threshold are surplus; they transfer to next-ranked picks. If no candidate meets threshold, the trailing candidate is eliminated, and ballots in their column transfer to next-ranked picks. Ballots without next-ranked picks sometimes lead to quota re-calculation. The count iterates between surplus transfer and elimination until all seats are filled. Surplus transfer may be at random (a subset of a winner's ballots) or by some fractional rule (a portion of each of a winner's ballots). See the Ranked Choice Voting Resource Center (2020) for details. If there is only one seat in the district, STV becomes the alternative vote (AV). The quota is a majority, and surplus cannot exist.

$\mathrm{AV}$ is used to elect roughly 20 local governments, in part or entirety. Six jurisdictions since 2000 have discontinued use: Aspen (CO), Burlington (VT), Cary (NC), Hendersonville (NC), Pierce County (WA), and North Carolina (for statewide judicial elections). A handful of states use AV for one or more party primaries/ conventions. Maine uses it in primaries and federal general elections (FairVote, 2020). One recent innovation is 
to apply AV in the second round of a non-partisan tworound election. In Alaska, the only place to adopt this so far, four candidates will proceed to the AV round, regardless of party designation (Herz, 2020). Cary (NC) used a 'contingent vote' version, which let only the top two candidates receive vote transfers ("Cary chosen," 2007). Queensland, Australia also used this (1892-1942) to elect its unicameral legislature. Ann Arbor (MI) used AV for a partisan mayoral election in 1975, then summarily repealed it (Ratner, 2018). During the Progressive Era, 11 states used either AV or Bucklin voting for statewide party primaries (Weeks, 1937). Bucklin was the AV of its day and similar to it with one exception: candidates are not eliminated. Rather, in each round of counting, lower preferences are added to higher preferences, until a majority winner emerges (Hoag, 1914a, p. 10).

STV is used in Albany (CA), Eastpointe (MI), Palm Desert (CA), Cambridge (MA), Arden (DE), and Minneapolis for park board elections (since 2006). The first three resulted from voting-rights claims (or threats thereof) against citywide plurality systems. Arden has used STV since 1912, when it was a single-tax colony (Proportional Representation League, 1915, p. 3). Cambridge retains STV from an earlier reform wave, 1915-1947, when 23 cities adopted it as part of councilmanager charters. One more, New York City, combined STV with a separation-of-powers system (Amy, 1996; Santucci, 2017; Weaver, 1986).

A third version is the bottoms-up system, used for some South Australian local-council elections until 1999 (Sanders, 2011, p. 703). Like STV, it uses multi-seat districts, but there is no quota (and hence no surplus redistribution). Trailing candidates are eliminated, and their ballots redistributed, until all seats in a district are filled. Recently, reformers in Missouri have sought to impose 'bottoms-up' for state-legislative elections, in tandem with reducing the size of that assembly (Ballotpedia, 2021). Five states used a modified version for 2020 Democratic presidential primaries. District magnitude was the number of delegates in each jurisdiction. In contrast to 'standard' bottoms-up, however, transfers brought candidates to $15 \%$ (per Democratic National Committee rules). Then, candidates earned delegates in proportion to their final-round vote shares (as such, votes for candidates functioned as votes for parties would in a proportional system where voters rank parties, not candidates).

Fourth is the block-preferential vote (BPV), exhaustive preferential system, sequential RCV, or instant runoffs (plural). This applies AV to a multi-seat election. Voters rank all candidates at once, but each seat gets a separate tabulation. The win threshold is a majoritynot an STV quota. After the first candidate is elected, all ballots in their pile count toward next-ranked choices at full value. Other ballots count toward highest-ranked choices who have not been elected. Elimination occurs within a tabulation if someone cannot get to a majority. The process repeats until all seats are filled. Currently, any Utah city opting into RCV with multi-seat districts must use BPV (Municipal Alternative Voting Methods Pilot Project, 2019). Other places considering BPV are Missouri, along the lines of the Utah law (Stacy, 2021), and Arlington (MA; Town of Arlington, 2021, p. 32). The system is called 'block' because it uses AV to build up a full slate. In that, it is related to multi-seat plurality (wherein the voter may cast as many votes as there are seats), commonly called 'block vote.'

Finally, AV can be used with numbered-post elections. Progressives achieved a functional equivalent by combining the Bucklin system with the commission form of government (Bucklin, 1911; Johnson, 1914; Porter, 1914). Under commission government, candidates would run citywide in a series of 'numbered posts,' which, at the time, corresponded to city departments (e.g., parks, water, roads). In modern times, these posts become, e.g., Seat A, Seat B, Seat C. The candidate declares which seat (post) they are contesting, and the election is city-(or district-)wide. It is similar to BPV in that the same districtwide majority gets to fill every seat.

Any RCV system now (or formerly) appearing in the US-AV, STV, bottoms-up, BPV, and AV with numbered posts - can be combined with rules that encourage slate voting. Australian federal politics have been conspicuous for these: grouping co-partisans on the ballot, permitting voters to ratify a predetermined set of rankings (which may include multiple parties), and/or requiring some minimum number of rankings (Reilly, 2021; Reilly \& Maley, 2000). Australia also is the only jurisdiction to have used AV for legislative elections, over many decades, without seeing it repealed. Another basic issue is whether ballots include party labels at all, or, if they do, whether a party gets to present a single slate (e.g., versus in Alaska).

As the next two sections show, how and whether voters use rankings is important for winning-minded elites. Note that three related RCV modifications were debated in American history. A so-called Gove (1894) system would have let the voter choose one candidate and, by extension, that person's rank-ordering. In New Jersey, where Bucklin-commission was widespread, a ballot was invalid unless the voter ranked at least one candidate for each numbered post (Rosenthal \& Santucci, 2021). Two of 11 states with majoritarian ranked-ballot primaries required at least two rankings (Weeks, 1937, p. 65). Finally, in American history, reformers got support for STV by combining it with party-free ballots, nominationby-petition, and reduction of assembly size (i.e., councilmanager reform). See Thompson (1913, pp. 421-426) for related critique of "the so called non-partisan idea."

\section{Simple Model of Ranked Voting with Two Parties}

This section demonstrates seat-share outcomes for a polarized electorate that can rank all choices, building on Santucci and Reilly (2020), with credit to political scientist Andy Eggers. 
Let there be 100 voters in a city with a three-seat assembly. There are 26 candidates, $A-Z$. 51 voters rank them A, B... Z. 49 voters rank in reverse: Z, Y... A. To keep things simple, let the pure $A V$ election be to just one seat (e.g., mayor).

Under AV, Party A wins in the first round of counting. In AV with numbered posts, Party $A$ wins all three seatseven if Party $Z$ has a majority in some neighborhood.

Under STV, the quota is $100 /(3+1)+1=26$. A gets the first seat. Their surplus $(51-26=25)$ transfers to $B$, now one vote shy of threshold. $Z$ is the next candidate with a quota, and they get the second seat. Their surplus $(49-26=23)$ transfers to $\mathrm{Y}$. All trailing candidates are eliminated, as none has votes to contribute. $B$ gets the third seat, with more votes than Y. Result: 2 for Party A, 1 for Party $Z$.

Under bottoms-up, A and Z get seats. No other candidate had votes to contribute on elimination. The council is left with a vacancy. This is unlikely in practice, however, because parties typically run as many candidates as they expect to win (see note on 'spread the preferences' in the next section).

Finally, under BPV, Party A candidates win all three seats. A gets the first seat. All their votes transfer, at full value, to candidate $B$. In the second tabulation, $B$ gets the seat (now with 51 votes from $A$ ). All their votes transfer, at full value, to candidate $C$. In the third tabulation, $C$ gets the seat (with 51 votes from $B$, which originated with $A$ ).

\section{Strategic Implications for Two-Party Politics}

The scenarios above demonstrate (or allude to) several strategic aspects of the varied RCV systems. These include effects on minority representation, outcomes when party cues do not structure rankings (which they did do above), outcomes when voters rank too few choices (which voters did not do above), and what happens if like-minded voters do not distribute their support efficiently among preferred candidates (e.g., leading to the empty seat under bottoms-up).

First, in polarized electorates, two of the three multiseat rules do not provide minority representation: BPV and AV numbered-post. This is consistent with experience. BPV's most prominent use was for Australian Senate elections, 1919-1946, where 55 of 60 such races produced single-party sweeps: "All five deviant cases, moreover, arose in the first decade of the system's operation; thereafter it functioned exclusively as a winnertakes-all system" (Reilly \& Maley, 2000, pp. 42-43, 57). Similar results have occurred in Australian local elections (Sanders, 2011). In the US, Progressive Era advocates of ranked ballots abandoned numbered-post for this reason (Hoag, 1914b, p. 54; Thompson, 1913, p. 420). Note that bottoms-up can replace either system if STV and single-seat districts are politically unworkable (and ranked ballots must be used).

Second, the scenarios illustrate what happens when party cues do not structure voters' rankings. A survey of the US literature suggests that unstructured rankings can lead to elite disaffection, efforts to get control of voters' rankings, and even more efforts to change the electoral system. In the past, such efforts have come from reform opponents, as well as reformers themselves.

One set of frustrations stems from 'vote leakage,' i.e., when transfers cross party lines (Gallagher, 1978). This encompasses two possible issues. One is majority reversal, e.g., votes leave Party $A$, then help Party $B$ win more seats. An example of this occurred in Cincinnati, 1955 , when the Republican Party won a majority of firstchoice votes, but the 'good government' slate won a seat majority (author's work-in-progress). Some might cast this as a 'pro' for STV, allowing alternative issue dimensions to shape seat allocation. It is worth noting, however, that this was Cincinnati's last election under STV rules. Further, as noted in the introduction, blaming STV for a 'lottery effect' was common in such repeal efforts.

A second 'leakage' problem might be called two masters-when one party's winners owe their seats to voters from a different party. This is especially likely when a party over-nominates, i.e., runs more candidates than it can elect. It is rational to do this if expectations are unclear (e.g., where the RCV party system does not track voter registration). The strategist recruits a slate of neighborhood candidates, per normal STV strategy (Bowler \& Farrell, 1991, p. 305; Carty, 1981; Schulze, 2011 , p. 22), then pads its shared vote with transfers from hopeless candidates (Bentley, 1926, p. 466). If candidates know they are hopeless, they may seek transfers elsewhere. In turn, if elected, they may feel beholden to voters whose transfers got them into office (Reilly, 2018, pp. 211-216; Reilly \& Stewart, 2021). Whether two masters is virtue or vice depends on the value of party cohesion.

One last problem with unstructured rankings is ranking truncation, or when a voter does not rank all candidates. This can result from indifference, protest voting, or from failure of elites to coordinate on likely winners. Most truncation is innocuous. However, when it leads to winners without full quotas of total ballots cast, it is common to refer to the rate of 'ballot exhaustion.' Analysts of ballot exhaustion have tended to study $\mathrm{AV}$, pointing out winners without overall vote majorities (Burnett \& Kogan, 2015; Kilgour, Grégoire, \& Foley, 2020). But in multi-seat elections, we may care about legislative majorities. In the STV example above, Party A won a majority because its voters did give candidate $B$ their second choices. This did not happen in New York City, where, at the first STV race in 1937, reformers failed to win a seat majority. McCaffrey (1937, p. 45) writes: "The Democrats won two or three more places than their proportion of first choices would have entitled them to receive because of the large number of exhausted ballots cast by members of the opposition."

Responses to unstructured rankings-or rankings that do not accord with reformers' expectations-have taken several forms. One is outright repeal, as noted 
above with respect to STV in Cincinnati. Alvarez, Hall, and Levin (2018) and Eberhard (2017) document such an outcome under AV in Pierce County (WA). The former compared ballot data from partisan and nonpartisan races in 2008. In the partisan races, most voters ranked their preferred party's candidates. In the nonpartisan race, rankings reflected other factors. None of this is surprising. One year later, however, leaders in both parties orchestrated AV's repeal, responding to an independent victory in the nonpartisan race. Meanwhile, in Cleveland under nonpartisan Bucklin (1913-1919), "Alternative votes of the independent voters would tend to build up the aggregate vote of the party candidates, but the regular party voters would contribute nothing to the aggregate vote of the independent candidates" (Maxey, 1922, p. 85). In this case, party cues did structure voters' rankings-just not in the way that reformers had hoped. Hence, they abandoned Bucklin for STV, seeking direct representation via the non-majority quota (Barber, 1995, pp. 120-124).

Another response to unstructured rankings, mainly under STV, was to create de facto parties in response to adverse outcomes. This was common practice in US cities at the end of the Progressive Era, based on a 'lessons-learned' report for the National Municipal League (Harris, 1930). In turn, Gosnell (1930) analyzed aggregate transfers in the city where these 'good government' parties had been perfected. He found that "rivalry between the [reform slate] and the organization Republican party outweighed all other factors" (p. 471). This rivalry also shaped descriptive representation. The party stopped slating women and blacks until it came to believe those groups would reliably provide transfers to the slate's other members (Burnham 1997, p. 139, 2013, p. 56; Santucci, 2018b; cf. Benade, Buck, Duchin, Gold, \& Soo, 2021).

There are several ways to deal with unstructured rankings. One is to require voters to rank all candidates, as Australia does federally with AV and once did with STV. Another is to permit ticket voting, which raises questions about who should constitute a ticket (Muller, 2018). The Maltese solution is to allocate seats based on parties' first-choice vote totals (Hirczy de Miño \& Lane, 2000 , p. 183). Finally, one can replace STV with openlist proportional representation, getting rid of rankings and transfers altogether. In a paper that largely went ignored, Gosnell (1939) proposed just such a change, having examined STV returns from New York City and Cincinnati (also see Lien, 1925, p. 265). With open-list proportional representation, votes for candidates determine two things: how many seats each party will get, then who in those parties will get seats. Ranking truncation and vote leakage are nonissue in open-list proportional representation.

This section has pointed out some strategic issues with two-party politics under ranked ballot. It has not delved deeply into issues of vote management, i.e., ensuring that slate candidates each have enough high rankings to survive early-round elimination. The discus- sion of neighborhood candidates alluded to a spreadthe-preferences strategy, and STV with parties might make it important (e.g., the Fair Representation Act, which would apply STV to US House elections). In addition to rationing nominations, spread-the-preferences involves evening out the first-choice-vote distribution (Farrell, Mackerras, \& McAllister, 1996, p. 34). Note that, in the bottoms-up example, the third seat did not get filled because neither party had 'spread the preferences.' Other issues not covered here are ballot-order effectsas in Australia (Orr, 2002), Scotland (Curtice \& Marsh, 2014), and Boulder (CO; Sowers, 1934, p. 34)-as well as the politics of filling casual vacancies (Miragliotta \& Sharman, 2017; Straetz, 1958, p. 80).

\section{Simple Model of Ranked Voting with Three Parties}

Say that candidates $M$ and $N$ have launched their own party in the 'middle' of the spectrum. Another way to think about this 'centrist' party is that it has found an issue that splits the majors' coalitions (cf. Nagel, 2006, p. 146). Examples are Ross Perot in 1996, or Ralph Nader in 2000. Four voters rank N, M, L... A. Three voters rank $M$, $\mathrm{N}, \mathrm{O} \ldots \mathrm{Z}$. This shared $7 \%$ is inspired by the share of pure independents in the 2019 US electorate (LaLoggia, 2019). Each third-party group aims to keep votes away from its main competitor, although, in practice, they might gang up on largest Party $A$ (Laver, 2000). The overall vote distribution is $A-Z$ (47), Z-A (46), N-A (4), M-Z (3). Again, for simplicity, let the pure AV election be to just one seat.

In $\mathrm{AV}$ and $\mathrm{AV}$ with numbered post, Party $\mathrm{A}$ wins all seats. Since no candidate has a majority, all candidates without votes are eliminated. Then $\mathrm{M}$ is eliminated, and their ballots flow to $\mathrm{N}$ (now with seven). Still, no candidate has a majority. $\mathrm{N}$ is then eliminated; four votes go to $A$ (now with 51), and three votes go to $Z$ (now with 49).

In STV, competition is for the third seat. A and $Z$ win outright, transferring surplus to $B$ and $Y$, who enter the next round with 21 and 20 votes, respectively. Neither has a quota, so all candidates without votes are eliminated. That leaves B (21 votes), Y (20 votes), N (4 votes), and $M$ ( 3 votes). Then $M$ is eliminated, and three ballots flow to $\mathrm{N}$ (7 votes). In the following round, three $\mathrm{N}$ ballots flow to $Y$ (23 votes), and the other four go to B (24 votes). $B$ then gets the third seat by default.

With bottoms-up, three parties get one seat each. Round one eliminates all but $A, Z, M$, and $N$. Then $M$ is eliminated. Their three ballots flow to N. With just three candidates remaining, all seats are filled: $\mathrm{A}, \mathrm{Z}$, and $\mathrm{N}$.

Finally, with BPV, Party A sweeps the district. No candidate has an outright majority. $M$ is eliminated, and their four ballots flow to N. Now with seven votes, $N$ is eliminated. Four of these votes land with $A(47+4=51)$. The other three votes land with $Z(46+3=49)$. A now has a majority, taking the first seat. $B$ and $C$ enter the second and third tabulations, respectively, with A's 47 votes. As the process repeats, $\mathrm{B}$ and also $\mathrm{C}$ win. 


\section{Strategic Implications for Multi-Party Politics}

Everything noted in Section 4 still applies with a third party. New insights are as follows.

First, results are sensitive to minor change in the vote distribution across pivotal groups, just as under 'conventional' plurality. If one $\mathrm{N}-\mathrm{A}$ voter had ranked $\mathrm{M}-\mathrm{Z}$ instead, the AV and BPV elections would have tied. In bottoms-up, the third seat would have gone to $M$, not N. In STV, seat three would have gone to $Y$, not B. A two-vote shift would turn the ties into wins for Party Z.

How might one deal with the unpredictability of thirdparty/independent voters? Potential solutions may not sit well with those who oppose parties writ large, nor with those who oppose multi-party politics. One is simply to have more parties, so that voters can rank choices based on a sense of 'party family' (cf. Clark, 2021; Clark \& Bennie, 2008). Another is for $\mathrm{M}$ and $\mathrm{N}$ to control a disciplined party. While that party still would be pivotal, it could cut deals with other parties as parties (Sharman, Sayers, \& Miragliotta, 2002).

Finally, STV appears to blunt the impact of the $M$ and $\mathrm{N}$ groupings. Under each majoritarian system, they can change the entire result. With bottoms-up, one of them is able to win a seat (hence the importance for major parties of nominating the right number and 'spreading the preferences'). With STV, however, $\mathrm{M}$ and $\mathrm{N}$ only change which major party has a seat majority. For those who view STV as 'proportional' (but see Farrell \& Katz, 2014), this is counterintuitive. Many expect such systems to enhance the role of 'outsiders' (cf. Hermens, 1941; but see Lien, 1941). While the adoption of proportional representation is beyond the scope of this article, dealing with threats from 'outsiders' is a major part of that story (see, e.g., Ahmed, 2010; Cox, Fiva, \& Smith, 2019).

\section{Conclusion}

This article has described the different kinds of RCV used for public elections in the US, historically and in modern times, drawing on comparative cases. These include rarely-used (for now) and less-understood systems like bottoms-up, BPV, and AV with numbered posts. The standard versions are AV and STV, although, as we have seen, the ecosystem is more complicated. Seemingly small and technical distinctions matter. Different allocation rules can produce different outcomes with identical vote and ranking distributions. In turn, those different allocation rules have predictable effects-given polarized votingon minority representation.

Meanwhile, elites matter-not just whether voters are strategic. Minor variations in vote and ranking distributions can produce different outcomes with the same RCV type. Such systems therefore carry many of the same strategic issues as plurality, except with allowance for 'expressive' first-choice voting. Hence the strategist is apt to care about how and whether voters rank choices.
The article covered some strategic issues with party and party-like competition in RCV: vote leakage (with derivative problems of majority reversal and two masters), ranking truncation, issues of vote management (the need to nominate strategically and manage a vote distribution across like-minded candidates), and the need for stable coalition (to deal with otherwise unpredictable third parties/independents). The US literature suggests that some of these issues have come up in RCV repeal campaigns.

The sorts of dynamics noted in this article may not resonate with some reformers, as their work centers (for now) on "expanding voter choice" (e.g., FairVote, 2015). Rather, strategy tends to matter later on, as coalitions settle in, and normal politics resumes. One such issue is certain variants' potential, given polarized voting, to cut off minority representation. This potential relates to district structure and allocation rule-two sometimesoverlooked aspects of the myriad RCV systems. Another set of issues relates to parties' role in a democracyespecially whether we expect (or want) them to structure voters' rankings.

A broader question is whether RCV can be used to induce multi-party politics. Maybe it can (cf. Duverger, 1954), and maybe it cannot (cf. Colomer, 2005). If one wants more parties in legislatures, STV is better than AV in any form (Jansen, 2004). Far more important is the interaction of district magnitude and assembly size (Shugart \& Taagepera, 2017). Less obvious, as shown above in the case of bottoms-up, is that major-party coordination failure may create the real openings (cf. Maeda, 2012). Whatever form RCV takes, if one wants to avoid repeal at the hands of opposing 'party bosses,' coalitions need some measure of control of voters' rankings. For example, Drutman (2020, pp. 184-185) recommends Australian-style ticket voting. But most of this gets back to adoption where more than two parties do not yet exist. History suggests the price has been designing RCV systems to 'get parties out of politics.'

\section{Acknowledgments}

The author thanks Michael Maley, Benjamin Reilly, Twitter user @Clashlrony, and four anonymous reviewers. Thanks also to Caroline Tolbert for coordinating this thematic issue.

\section{Conflict of Interests}

The author declares no conflict of interests.

\section{References}

Ahmed, A. (2010). Reading history forward: The origins of electoral systems in European democracies. Comparative Political Studies, 43(8/9), 1059-1088. https://doi.org/10.1177/0010414010370436

Aldrich, J. (1995). Why parties? The origin and transfor- 
mation of political parties in America. Chicago, IL: University of Chicago Press.

Alvarez, R. M., Hall, T. E., \& Levin, I. (2018). Lowinformation voting: Evidence from instant-runoff elections. American Politics Research, 46(6), 1012-1038. https://doi.org/10.1177/1532673X187 59643

Amy, D. J. (1996). The forgotten history of the single transferable vote in the United States. Representation, 34(1), 13-20. https://doi.org/10.1080/ 00344899608522981

Ballotpedia. (2021). Missouri ranked choice voting and changes in composition for state legislature (2022). Ballotpedia. Retrieved from https://ballotpedia.org/ Missouri_Ranked_Choice_Voting_and_Changes_ in_Composition_for_State_Legislature_Initiative_ (2022)

Barber, K. L. (1995). Proportional representation and electoral reform in Ohio. Columbus, $\mathrm{OH}$ : Ohio State University Press.

Benade, G., Buck, R., Duchin, M., Gold, D., \& Weighill, D. (2021). Ranked choice voting and minority representation. Unpublished manuscript. Retrieved from https://ssrn.com/abstract=3778021

Bentley, H. (1926). Cincinnati's right about face in government. National Municipal Review, 15(8), 465-473. https://doi.org/10.1002/ncr.4110150808

Bowler, S., \& Farrell, D. M. (1991). Voter behavior under STV-PR: Solving the puzzle of the Irish party system. Political Behavior, 13(4), 303-320. https://doi.org/ 10.1007/BF00992866

Bridges, A., \& Kronick, R. (1999). Writing the rules to win the game: The middle-class regimes of municipal reformers. Urban Affairs Review, 34(5), 691-706. https://doi.org/10.1177\%2F10780879922184149

Bucklin, J. W. (1911). The Grand Junction plan of city government and its results. Annals of the American Academy of Political and Social Science, 38(3), 87-102. https://doi.org/10.1177/000271621103800 307

Burnett, C. M., \& Kogan, V. (2015). Ballot (and voter) "exhaustion" under instant runoff voting: An examination of four ranked-choice elections. Electoral Studies, 37, 41-49. https://doi.org/10.1016/j.electstud. 2014.11.006

Burnham, R. A. (1997). Reform, politics, and race in Cincinnati: Proportional representation and the City Charter Committee, 1924-1959. Journal of Urban History, 23(2), 131-163. https://doi.org/10.1177/ 009614429702300201

Burnham, R. A. (2013). Women and reform in Cincinnati: Responsible citizenship and the politics of 'good government,' 1924-1955. Ohio Valley History, 13(2), 48-69.

Carty, R. K. (1981). Party and parish pump: Electoral politics in Ireland. Waterloo, ON: Wilfred Laurier University Press.

Cary chosen to test new voting method for runoffs.
(2007, October 2). WRAL.com. Retrieved from https://www.wral.com/news/local/politics/story/ 1886176

Cheyne, C., \& Comrie, M. (2005). Empowerment or encumbrance? Exercising the STV option for local authority elections in New Zealand. Local Government Studies, 31(2), 185-204. https://doi.org/ $10.1080 / 03003930500032064$

Clark, A. (2021). The effects of electoral reform on party campaigns, voters and party systems at the local level: From single member plurality to the single transferable vote in Scotland. Local Government Studies, 47(1), 79-99. https://doi.org/10.1080/ 03003930.2020 .1816544

Clark, A., \& Bennie, L. (2008). Strategic actors or muddling through? Political parties, local campaigning, and the single transferable vote. Representation, 44(4), 327-340. https://doi.org/10.1080/ 00344890802422922

Colomer, J. (2005). It's parties that choose electoral systems (or, Duverger's Laws upside down). Political Studies, 53, 1-21. https://doi.org/10.1111/j.14679248.2005.00514.x

Cox, G. (1997). Making votes count: Strategic coordination in the world's electoral systems. Cambridge: Cambridge University Press.

Cox, G., Fiva, J., \& Smith, D. M. (2019). Parties, legislators, and the origins of proportional representation. Comparative Political Studies, 52(1), 102-233. https://doi. org/10.1177\%2F0010414018762369

Curtice, J. (2007). STV goes Tartan: A preliminary analysis of its use in the 2007 Scottish elections. Representation, 4(3). https://doi.org/10.1080/0034489070 1463688

Curtice, J., \& Marsh, M. (2014). Confused or competent? How voters use the STV ballot paper. Electoral Studies, 34, 146-158. https://doi.org/10.1016/ j.electstud.2013.11.002

Drutman, L. (2020). Breaking the two-party doom loop: The case for multiparty democracy in America. New York, NY: Oxford University Press.

Duverger, M. (1954). Political parties: Their organization and activity in the modern state. New York, NY: John Wiley \& Sons.

Eberhard, K. (2017, September 19). What really happened with instant runoff voting in Pierce County, Washington? Sightline Institute. Retrieved from https://www.sightline.org/2017/09/19/what-reallyhappened-with-instant-runoff-voting-in-piercecounty-washington

FairVote. (2015). Comparative structural reform: Assessing strategies for improving American elections. Takoma Park, MD: FairVote. Retrieved from http:// archive3.fairvote.org/assets/Uploads/ComparativeStructural-Reform-Summary.pdf

FairVote. (2020). Where ranked choice voting is used. FairVote. Retrieved from https://www.fairvote.org/ where_is_ranked_choice_voting_used 
Farrell, D. M., \& Katz, R. S. (2014). Assessing the proportionality of the single transferable vote. Representation, 50(1), 13-26. https://doi.org/10.1080/ 00344893.2014.902212

Farrell, D. M., Mackerras, M., \& McAllister, I. (1996). Designing electoral institutions: STV systems and their consequences. Political Studies, 44(1), 24-43. https://doi.org/10.1111/j.1467-9248.1996. tb00755.x

Farrell, D. M., \& McAllister, I. (2006a). The Australian electoral system: Origins, variations, and consequences. Sydney: University of New South Wales Press.

Gallagher, M. (1978). Party solidarity, exclusivity, and inter-party relationships in Ireland, 1922-1977: The evidence of transfers. Economic and Social Review, 10(1), 1-22.

Gallagher, M. (2005). Ireland: The discreet charm of PRSTV. In M. Gallagher \& P. Mitchell (Eds.), The politics of electoral systems (pp. 511-523). Oxford: Oxford University Press.

Gehl, K. M., \& Porter, M. E. (2020). The politics industry: How political innovation can break partisan gridlock and save our democracy. Boston, MA: Harvard Business Review Press.

Gosnell, H. F. (1930). Motives for voting as shown by the Cincinnati P.R. election of 1929. National Municipal Review, 19(7), 471-476. https://doi.org/10.1002/ ncr.4110190708

Gosnell, H. F. (1939). A list system with single candidate preference. American Political Science Review, 33(4), 645-650. https://doi.org/10.2307/194949617

Gove, W. H. (1894). The relation of the Gove system to other methods of proportional representation. Proportional Representation Review, 2(6), 41-47.

Harris, J. P. (1930). The practical workings of proportional representation in the United States and Canada. National Municipal Review, 19(5), 3-50. https://doi. org/10.1002/ncr.4110191402

Hermens, F. A. (1941). Democracy or anarchy? A study of proportional representation. Notre Dame, IN: University of Notre Dame.

Herz, N. (2020, September 28). An initiative proposes to overhaul Alaska's elections. But not everyone thinks they're broken. Alaska Public Media. Retrieved from https://www.alaskapublic.org/2020/09/28/aninitiative-proposes-to-overhaul-alaskas-electionsbut-not-everyone-thinks-theyre-broken

Hirczy de Miño, W., \& Lane, J. C. (1996). STV in Malta: Some surprises. Representation, 34(1), 21-28. https://doi.org/10.1080/00344899608522982

Hirczy de Miño, W., \& Lane, J. C. (2000). Malta: STV in a two-party system. In S. Bowler \& B. Grofman (Eds.), Elections in Australia, Ireland, and Malta under the single transferable vote: Reflections on an embedded institution (pp. 178-204). Ann Arbor, MI: University of Michigan Press.

Hoag, C. G. (1914a). Effective voting: An article on preferential voting and proportional representation (Sen- ate Document No. 359). Washington, DC: United States Government Printing Office.

Hoag, C. G. (1914b). Proportional representation, preferential voting, and direct primaries. National Municipal Review, 3(1), 49-56. https://doi.org/10.1002/ncr. 4110030107

Jansen, H. (2004). The political consequences of the Alternative Vote: Lessons from Western Canada. Canadian Journal of Political Science, 37(3), 647-669. https://doi.org/10.1017/S0008423904030227

Johnson, L. J. (1914). Preferential voting: Its progress, with comments and warnings. National Municipal Review, 3(1), 83-92. https://doi.org/10.1002/ncr. 4110030111

Kilgour, D. M., Grégoire, J.-C., \& Foley, A. M. (2020). The prevalence and consequences of ballot truncation in ranked-choice elections. Public Choice, 184, 197-218. https://doi.org/10.1007/s11127-019-00723-2

LaLoggia, J. (2019, May 15). Six facts about U.S. political independents. Pew Research Center. Retrieved from https://www.pewresearch.org/fact-tank/2019/05/ 15/facts-about-us-political-independents

Laver, M. (2000). STV and the politics of coalition. In S. Bowler \& B. Grofman (Eds.), Elections in Australia, Ireland, and Malta under the single transferable vote: Reflections on an embedded institution (pp. 135-152). Ann Arbor, MI: University of Michigan Press.

Lien, A. J. (1925). Eight years of proportional representation in Boulder. Washington University Studies, 13, 247-266.

Lien, A. J. (1941). Review of the book "Democracy or anarchy? A study of proportional representation" by F. A. Hermens. National Municipal Review, 30(9), 553-554. https://doi.org/10.1002/ncr.4110300919

Maeda, K. (2012). An irrational party of rational members: The collision of legislators' reelection quest with party success in the Japan Socialist Party. Party Politics, 45(3), 341-365. https://doi.org/10.1177\% 2F0010414011421312

Maxey, C. C. (1922). The Cleveland election and the new charter. American Political Science Review, 16(1), 83-86. https://doi.org/10.2307/1943890

McCaffrey, G. H. (1937). New York's 1937 election and its results. National Municipal Review, 27(1), 39-45. https://doi.org/10.1002/ncr.4110270110

McCarthy, D., \& Santucci, J. (2021). Ranked-choice voting as a generational issue in modern American politics. Politics \& Policy, 49(1), 33-60. https://doi.org/ 10.1111/polp.12390

McGarry, J., \& O'Leary, B. (2006). Consociational theory, Northern Ireland's conflict, and its agreement, part 1: What consociationalists can learn from Northern Ireland. Government \& Opposition, 41(1), 43-63. https://doi.org/10.1111/j.1477-7053.2006. 00170.x 20

Miragliotta, N. \& Sharman, C. (2017). Managing midterm vacancies: Institutional design and partisan strategy 
in the Australian national parliament, 1901-2013. Australian Journal of Political Science, 52(3), 351-366. https://doi.org/10.1080/10361146.2017. 1325441

Muller, D. (2018). The new Senate voting system and the 2016 election (Research Paper Series 2017-17). Canberra: Parliament of Australia. Retrieved from https://parlinfo.aph.gov.au/parllnfo/download/ library/prspub/5753272/upload_binary/ 5753272.pdf

Municipal Alternative Voting Methods Pilot Project, 24A Utah Code $\S$ 4-603-7 (2019). Retrieved from https://le.utah.gov/xcode/Title20A/Chapter4/20A4-S603.html

Nagel, J. (2006). Occam no, Archimedes yes. In J. Bara \& A. Weale (Eds.), Democratic politics and party competition (pp. 143-158). London: Routledge.

Orr, G. (2002). Ballot order: Donkey voting in Australia. Election Law Journal, 1(4), 573-578. https://doi. org/10.1089/153312902760403914

Porter, M. P. (1914). Preferential voting and the rule of the majority. National Municipal Review, 3(3), 581-585. https://doi.org/10.1002/ncr.4110030316

Proportional Representation League. (1915). Adoption of P. R. by Ashtabula, Ohio. Proportional Representation Review, 36, 3-11.

Rae, D. W. (1967). The political consequences of electoral laws. New Haven, CT: Yale University Press.

Ranked Choice Voting Resource Center. (2020). Multiwinner ranked-choice voting in depth. Ranked Choice Voting Resource Center. Retrieved from https://www. rcvresources.org/types-of-rcv

Ratner, B. (2018). Ranked choice voting's moment in Ann Arbor. Takoma Park, MD: FairVote. Retrieved from https://www.fairvote.org/ranked_choice_voting_s_ moment_in_ann_arbor

Reilly, B. (2018). Centripetalism and electoral moderation in established democracies. Nationalism and Ethnic Politics, 24(2), 201-221. https://doi.org/10.1080/ 13537113.2018.1457827

Reilly, B. (2021). Ranked choice voting in Australia and America: Do voters follow party cues? Politics and Governance, 9(2), 271-279.

Reilly, B., \& Maley, M. (2000). The single transferable vote and Alternative Vote compared. In S. Bowler \& B. Grofman (Eds.), Elections in Australia, Ireland, and Malta under the single transferable vote: Reflections on an embedded institution (pp. 37-58). Ann Arbor, MI: University of Michigan Press.

Reilly, B., \& Stewart, J. H. (2021). Compulsory preferential voting, social media and 'come-from-behind' electoral victories in Australia. Australian Journal of Political Science, 56(1), 99-112. https://doi.org/10.1080/ 10361146.2021.1879010

Rosenthal, A., \& Santucci, J. (2021). The factional politics of nonpartisan reform: The rise and fall of ranked ballots in Progressive Era New Jersey. Unpublished manuscript.
Sanders, W. (2011). Alice's unrepresentative council: Cause for intervention? Australian Journal of Political Science, 46(4), 699-706. https://doi.org/10.1080/ 10361146.2011.623669

Santucci, J. (2017). Party splits, not progressives: The origins of proportional representation in American local government. American Politics Research, 45(3), 494-526. https://doi.org/10.1177/1532673X16674 774

Santucci, J. (2018a). Maine ranked-choice voting as a case of electoral-system change. Representation, 54(3), 297-311. https://doi.org/10.1080/00344893. 2018.1502208

Santucci, J. (2018b). Evidence of a winning-cohesion tradeoff under multi-winner ranked-choice voting. Electoral Studies, 52, 128-138. https://doi.org/ 10.1016/j.electstud.2017.11.003

Santucci, J., \& Reilly, B. (2020, January 23). Utah's new kind of ranked-choice voting could hurt political minorities: And sometimes even the majority. LSE American Politics \& Policy. Retrieved from https:// blogs.Ise.ac.uk/usappblog/2020/01/23/utahs-newkind-of-ranked-choice-voting-could-hurt-politicalminorities-and-sometimes-even-the-majority

Schulze, M. (2011). Free riding and vote management under proportional representation by the single transferable vote. Berlin: Humboldt University. Retrieved from http://www.9mail.de/m-schulze/ schulze2.pdf

Sharman, C., Sayers, A. M., \& Miragliotta, N. (2002). Trading party preferences: The Australian experience of preferential voting. Electoral Studies, 21(4), 543-560. https://doi.org/10.1016/S0261-3794(01)00012-9

Shugart, M., \& Taagepera, R. (2017). Votes from seats: Logical models of electoral systems. Cambridge: Cambridge University Press. https://doi.org/10.1017/ 9781108261128

Shugart, M., \& Taagepera, R. (2020). Predicting party systems from electoral systems. Oxford Research Encyclopedia of Politics. Retrieved from https://oxfordre.com/politics/view/10.1093/ acrefore/9780190228637.001.0001/acrefore9780190228637-e-1763

Slaughter, A. (2020, December 3). Welsh Greens welcome single transferable vote for future local elections. Green World. Retrieved from https:// greenworld.org.uk/article/welsh-greens-welcomesingle-transferable-vote-future-local-elections

Sowers, D. C. (1934). Sixteen years of P. R. in Boulder. National Municipal Review, 23(1), 27-30. https://doi. org/10.1002/ncr.4110230112

Stacy, D. (2021). An act to amend chapter 115, RSMo, by adding thereto two new sections relating to instant runoff voting (House Bill No. 1137). St. Louis, MO: Missouri House of Representatives. Retrieved from https://www.house.mo.gov/billtracking/bills211/ hlrbillspdf/0882H.05I.pdf

Straetz, R. (1958). PR politics in Cincinnati: Thirty-two 
years of city government through proportional representation. New York: NY: New York University Press.

Thompson, C. (1913). The vital points in charter making from a Socialist point of view. National Municipal Review, 2(3), 416-426. https://doi.org/10.1002/ ncr.4110020306

Town of Arlington. (2021). Report of the Select Board to the town meeting. Arlington, MA: Select Board. Retrieved from https://www.arlingtonma.gov/ home/showpublisheddocument/55916/ 637540902738200000

Trebbi, F., Aghion, P., \& Alesina, A. (2008). Electoral rules and minority representation in U.S. cities. Quarterly Journal of Economics, 123(1), 325-357. https://doi. org/10.1162/qjec.2008.123.1.325

Weaver, L. (1986). The rise, decline, and resurrection of proportional representation in local governments in the United States. In B. Grofman \& A. Lijphart (Eds.), Electoral laws and their political consequences (pp. 139-153). New York, NY: Agathon Press.

Weeks, O. D. (1937). Summary of the history and present status of preferential voting in state direct primary systems. The Southwestern Social Science Quarterly, 18(1), 64-67.

\section{About the Author}

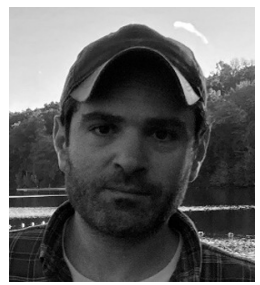

Jack Santucci is Assistant Teaching Professor of Political Science at Drexel University, teaching courses in American politics and political institutions. His research focuses on party change and electoral reform in the US. 